\title{
İnternet Bağımlıı̆ı̆: Güncel Bir Gözden Geçirme
}

\section{Internet Addiction: A Current Review}

\author{
Hasan Bozkurt', Serkan Şahin ${ }^{1}$, Salih Zoroğlu² \\ 1 Tokat Gaziosmanpaşa Üniversitesi Tıp Fakültesi, Çocuk ve Ergen Ruh Sağlığı ve Hastalıkları A.D., Tokat \\ 2 İstanbul Üniversitesi İstanbul Tıp Fakültesi, Çocuk ve Ergen Ruh Sağlığı ve Hastalıkları A.D. İstanbul
}

\section{ÖZET}

Dünya çapında sosyal bir sorun haline gelen internet bağımlılı̆̆ı, ge-nel olarak kişinin internet kullanımını günlük hayatta olumsuz sonuçlara yol açacak biçimde kontrol edememesi şeklinde tanımlanabilir. Mental Bozuklukların Tanısal ve Sayımsal El Kitabının Beşinci Basımı (DSM-5) ek bölümüne sadece internet oyun bağımlılığı dâhil edilse de internet bağımlılığının davranışsal bir bağımlılık geliştirecek şekilde internete ait diğer uygulamaların problemli kullanımını içerdiği uzun zamandır tartı-şılmaktadır. Bu yazıda internet bağımlılığı ile ilgili yazında giderek artan çalışmaların güncel olarak derlenmesi amaçlanmıştır.

Anahtar kelimeler: İnternet bağımlılı̆ı, problemli internet kullanı-mı, bağımlı davranış

\section{ABSTRACT}

Internet addiction, which has become a global social issue, can be broadly conceptualized as an inability to control one's use of the Inter-net which leads to negative consequences in daily life. Only Internet Gaming Disorder has been included in the appendix of the diagnostic and statistical manual of mental disorders fifth edition (DSM-5), but it has already been argued that Internet addiction could also comprise problematic use of other Internet applications developing an addictive behavior. This paper aims to give a current review of the gradually evolv-ing body of literature on Internet addiction.

Key words: Internet addiction, problematic Internet use, addictive behavior
Corresponding Author: Hasan Bozkurt

Address: Tokat Gaziosmanpaşa Üniversitesi Tıp Fakültesi,

Çocuk ve Ergen Ruh Sağlığı ve Hastalıkları A.D., Tokat

E-mail: drhasan33@gmail.com
Başvuru Tarihi/Received: 22-02-2016

Kabul Tarihi/Accepted: 21-03-2016 


\section{Giriş̧}

Internet bağımlılığı genel olarak internetin aşırı kullanılması isteğinin önüne geçilememesi, internette geçirilen süreye gittikçe daha fazla ihtiyaç duyulması, internete bağlı olmadan geçirilen zamanın önemini yitirmesi, yoksun kalındığında aşırı sinirlilik, gerginlik, huzursuzluk gibi hallerin ortaya çıkması ve kişinin iş, sosyal ve ailevi hayatının giderek bozulması olarak tanımlanabilir (1).

Birçok kişi için bağımlılık kavramı klasik anlamda alkol, esrar, kokain, eroin gibi kimyasal madde kullanımını içerir fakat kumar, seks, alışveriş, televizyon izleme, bilgisayar oyunları oynama gibi kimyasal olmayan davranışsal bağımlılıklar da söz konusudur. Davranışsal bağımlılıklar da tıpkı alkol-madde bağımlılıklarında olduğu gibi bağımlıı̆̆ın ana bileşenleri olan fiziksel ve psikolojik bağımlılık belirtilerini (zihinsel meşguliyet, duygudurum değişkenliği, tolerans, yoksunluk, kişilerarası çatışma ve tekrarlama) gösterirler (2). Mental Bozuklukların Tanısal ve Sayımsal El Kitabının Beşinci Basımı (DSM-5) ana bölümünde internet bağımlılığı ile ilgili bir yer olmasa da ek bölümde gelecekte sınıflandırmaya girmesi planlanan internet oyun bağımlılığı konusu yer almaktadır.

$\mathrm{Bu}$ gözden geçirme yazısında sıklığı gittikçe artan ve klinik pratikte dikkat çekmeye başlayan internet bağımlılığı ile ilgili güncel son bilgilerin mevcut literatür ışığında derlenmesi ve tartışı|ması amaçlanmıştır.

\section{Tanımlama ve Tanısal ölçütler}

Internet kullanımının yaygınlaşması ile birlikte internetin olası zararları da tartışılmaya başlamıştır. Bu alandaki çalışmaların hemen hepsi, internet kullanımının zaman zaman kişinin kendi denetiminden çıktığı ve sosyal ya da mesleki/akademik işlevsellikte bozulmaya neden olduğu varsayımı ile yapılmıştır (3). Ayrıca internet başında uyumadan günler geçirip ölen gençlere dair olgu bildirimleri (4), bu konunun giderek daha popüler bir nitelik kazanmasına neden olmuştur.

"Sağlıklı internet kullanımı" düşünsel, davranışsal herhangi bir rahatsızlık duymaksızın, uygun bir zaman diliminde, istendik amaca ulaşmak için internet kullanımıdır (5). Bazı bireyler internet kullanımını gereksinim duydukları miktarla sınırlarken, bazılarının bu sınırlamayı yapamadığı, iş ve sosyal yaşamlarında aşırı kullanım nedeniyle bazı sorunlar yaşadıkları görülmüştür. İnternet kullanımı davranışını sorun düzeyinde tanımlarken değişik araştırıcılar farklı nedenselliklere dayanarak farklı ifadeler kullanmıştır. Bunlar "internet bağımlılığı", "patolojik internet kullanımı", "problemli internet kullanımı", "aşırı internet kullanımı", "kompulsif internet kullanımı" ve hatta "internetomani" olarak sayılabilir (6).

Illk kez Ivan Goldberg (1996) "internet bağımılığı" terimini tanımlamış ve tartışmaya açmıştır (7). Goldberg DSM-IV'teki madde bağımlıı̆̆ tanı ölçütleri doğrultusunda internet bağımlılığı için göstergeler geliştirmiştir. Aynı yıllarda Young (1996), DSM-IV'ün patolojik kumar oynama tanı ölçütlerini temel alarak internet bağımlıığını tanımlamıştır (8). Young'un tanımladığı 8 ölçütten 5 tanesinin karşılanması durumunda kişi "internet bağımlısı" olarak tanı almaktadır (Tablo 1).

Tablo 1: Young'un İnternet Bağımlılığı için Önerdiği Tanı Ölçütleri

1. İnternet ile ilgili aşırı zihinsel uğraş (sürekli olarak interneti düşünme, internette yapılan aktivitelerin hayalini kurma, internette yapılması planlanan bir sonraki etkinliği düşünme, vb)

2. İstenilen keyfi almak için giderek daha fazla oranda internet kullanma ihtiyacı duyma

3. Interneti kullanımını kontrol etme, azaltma ya da tamamen bırakmaya yönelik başarısız girişimlerin olması

4. Internet kullanımının azaltılması ya da tamamen kesilmesi durumunda huzursuzluk, çökkünlük ya da kızgınlık hissedilmesi

5. Başlangıçta planlanandan daha uzun süre internette kalma

6. Aşırı internet kullanımı nedeniyle aile, okul, iş ve arkadaş çevresiyle sorunlar yaşama, eğitim veya kariyer ile ilgili bir firsat tehlikeye atma ya da kaybetme

7. Başkalarına (aile, arkadaşlar, terapist, vb) internette kalma süresi ile ilgili yalan söyleme

8. İnterneti problemlerden kaçmak veya olumsuz duygulardan (örn: çaresizlik, suçluluk, çökkünlük, kaygı) uzaklaşmak için kullanma

Bu alandaki araştırmalar, internetin de giderek yaygınlaşması ile birlikte sürekli artmaktadır. Griffiths (1999) internet bağımlılı̆ını teknolojik bağımlılığın bir çeşidi olarak değerlendirmiş ve Tablo 2'de belirtilen ölçütleri karşılayan davranışı "bağımlı davranış" olarak tanımlamıştır (9). 
Tablo 2: Griffiths'e Göre Bağımlı Davranış Ölçütleri.

1- Dikkat çekme: Belirli bir eylem, kişinin yaşamında ya da düşüncelerinde en önemli şey haline geldiğinde ortaya çıkar. Düşüncelere (zihinsel meşguliyet ya da bilişsel çarpıtma), duygulara şiddetli istek ve davranışa (sosyalleşmiş davranış bozuklukları) hakim olur. (Örneğin, internet kullanıcıları, internette olmasalar bile bağlanacakları zamanı düşünürler).

2- Duygudurum değişikliği: Bu durum, belirli bir etkinlik ile uğraşma sonucu kişinin belirttiği öznel deneyimlerdir ve bir baş etme stratejisi olarak görülebilir. (Örneğin, internete bağımlı kişilerde, internete bağlandıklarında bir "canlanma" görülmektedir).

3- Tolerans: İstenen etkiyi yaşamak için, özel eylemin miktarının arttırılması ya da bu aktivite için harcanan zamanın giderek arttrılması süreci. (Örneğin, bir internet kullanıcısının başlangıçta daha az sürede elde ettiği duygu-durumunu elde edebilmesi için internette kaldığı süreyi arttırması).

4- Yoksunluk: Bunlar belirli bir eylem devam etmediğinde ya da aniden kesildiğinde ortaya çıkan, hoş olmayan duygular ya da fiziksel etkilerdir. (Örneğin, bir internet kullanıcısının internete girmesi engellendiğinde titreme, huzursuzluk, sinirlilik yaşaması).

5- Çatışma: Bağımlı kişiler ile çevresindekiler arasındaki kişilerarası çatışmalar, iş, sosyal yaşam ve hobilerde yaşanan değişiklik, çatş̧malar ya da kişinin kendi içsel çatışmaları

6- Nüks: Belli bir aktivitenin daha önceki örüntüleriyle tekrar oluşması eğilimidir ve yıllar süren kaçınma ya da kontrolden sonra tekrar bağımlılığın en uç düzeyine dönülmesidir.

Beard ve Wolf (2001), Young'ın "internet bağımlılığı" tanı ölçütlerini düzenleyerek geliştirmişlerdir (10). Young'ın tanımladığı 8 ölçütü iki grupta toplamış, ilk 5'ini internet kullanım fonksiyonelliği olarak gruplandırmışlardır. Buna göre, kişinin her bir ifadedeki durumu mutlaka yaşamış olması gerekmektedir. Diğer 3 madde ise kişilerin internet kullanımından dolayı zarara uğraması olarak gruplandırılmış, internet bağımlılığı tanısı koyulabilmesi için ise, kişinin en az bir tanesini yaşamış olması gerekmektedir. Davis (2001), problemli internet kullanımı hakkında bilişsel-davranışçı bir model sunmuş ve problemli internet kullanımını sadece bir davranış bağımlıIığı olarak değil, yaşama olumsuz sonuçları olan, biliş ve davranışlarla belirli bir durum olarak nitelemiştir (11). Davis, patolojik internet kullanımını kullanma amacına göre 'özgül' ve 'yaygın' olarak ikiye ayırmıştır. Özgül tipte internet çevrimiçi seks, oyun, kumar, borsa takibi, alışveriş gibi özel amaçlar doğrultusunda kullanılır. Amaç doğrudan internet kullanımı değil bir hedefe ulaşmak için internetin kullanılmasıdır. Yaygın patolojik internet kullanımında ise, amaç doğrudan internet kullanımıdır ve kullanım amacı ya çok çeşitlidir, ya da açık bir amaç olmaksızın çok fazla zaman harcanması söz konusudur. Genellikle her an ulaşabilme ve ulaşılabilir olma gereksinimi vardır. "Online" yani "çevrimiçi" olunduğunda hissedilen sosyal bağ ve destek duygusu, çevrimiçi kalmaya yönelik motivasyonu artırır ve internet kişinin dış dünyayla olan ana bağlantısı haline gelir.
Shapira ve arkadaşları (2003) tanı kriterlerini biraz daha genişleterek "problemli internet kullanımı" adını verdikleri üç maddelik tanı ölçütü geliştirmiştir (12). Yine Ko ve arkadaşları (2005) "Chen İnternet Bağımlılığı Ölçeği” ismini verdikleri bir ölçek geliştirmiş ve internet bağımlılı̆ı için tanı ölçütleri ortaya atmıştır (13). İnternet kullanımını kompülsif kullanım, kesilme belirtileri, tolerans, kişilerarası sorunlar ya da sağlık sorunları ve zaman yönetiminde sorunlar gibi boyutlarla değerlendiren bu ölçek "Young İnternet Bağımlıı̆̆ı Ölçeği" ile birlikte birçok araştırmada oldukça yaygın olarak kullanılmaktadır. Yine Douglas ve arkadaşları (2008) internet bağımlılığı için içsel motivasyonların ve gereksinimlerin yönlendirmesini (itici faktörler), bireylerin yatkınlıklarını ve internetin çekici taraflarını dikkate alan (çekici faktörler) bir model önermiştir (14). Tao ve arkadaşları (2010) ise internet bağımlılığı tanısal kriterlerini semptom (yedi klinik belirti), işlevsellikte bozulma (fonksiyonel ve psikososyal), süre (bağımlılığın en az 3 ay boyunca devam etmesi ve günlük gereksiz internet kullanımının en az 6 saat olması) ve dışlama (psikotik bozukluk veya bipolar bozukluk) kriterleri şeklinde ayırarak uyarlamışlardır (15). Bu kriterler arasında problemli kullanım süresinin de belirtilmesi dikkat çekicidir (Tablo 3).

\section{Epidemiyoloji}

Tanı koyma ile ilgili metodolojik güçlükler ve tanısal araçların farklılığından dolayı internet bağımlılı̆ı̆ın prevalansı üzerine olan bilgiler sı- 
Tablo 3: Tao ve Arkadaşlarının Geliştirdiği İnternet Bağımlılığı Tanı Ölçütleri.

(a) Semptom kriteri

Aşağıdakilerden hepsi olmalıdır:

1. Internetle ilgili aşırı zihinsel uğraş (bir önceki çevrimiçi aktiviteyi düşünme veya bir sonraki aktiviteyi iple çekme)

2. Çekilme belirtileri, internetin kesilmesinden birkaç gün sonra disfori, anksiyete, irritabilite veya sıkılma hissinin olması Aşağıdakilerden en az biri (veya daha fazlasının) olması:

1. Tolerans, doyum sağlama amacıyla internet kullanımında belirgin artışın olması

2. İnternet kullanımını bırakmak veya denetim altına almak için sürekli bir istek ya da başarısız çabaların olması

3. Internet kullanımının yol açtı̆ı devamlı veya tekrarlayıcı fiziksel veya psikolojik bir probleme rağmen aşırı kullanıma devam edilmesi

4. Kullanımın direk bir sonucu olarak internet dışındaki aktivitelere ilgi ve istek kaybı

5. İnterneti disforik duygudurumdan (örneğin çaresizlik, suçluluk, kaygı gibi) kaçmak veya rahatlamak için kullanma

(b) Dışlama kriteri

Aşırı internet kullanımı psikotik bozukluk veya bipolar I bozukluk ile daha iyi açıklanamaz.

(c) Klinik olarak önemli derecede bozulma kriteri

Önemli bir ilişki, iş, eğitimsel veya mesleki firsatları kaybetmeyi de içerek şeklide işlevsel bozulmalar (azalmış sosyal, akademik, çalışma kapasitesi)

(d) Süre kriteri

İnternet bağımlılı̆̆ günlük en az 6 saat kullanım ile (iş/akademik amaçlı kullanım hariç) en az 3 ay sürmelidir.

nırlıdır. Durumun tanımlanması, isimlendirilmesi ve sınıflandırılmasına ilişkin uzlaşının olmaması, araştırıcıların farklı değerlendirme araçları geliştirmelerine yol açmıştır. Değerlendirme farklılıkları, aynı zamanda hem farklı ülkelerde, hem de aynı ülkede farklı araçlarla yapılan araştırmalarda birbirinden farklı yaygınlık oranları saptanmasına neden olmaktadır.

Ancak farklı ölçütlerle de olsa bugüne kadar yapılan çalışmalar problemli internet bağımlılığı yaygınlığının \% 0,3-38 arasında değiştiğini göstermektedir. Genel olarak erkeklerde kızlara oranla 2-3 kat daha fazla görülmekte ve internetin problemli kullanımına genç popülâsyonda daha çok rastlanmaktadır. Epidemiyolojik veriler Tablo 4'te özetlenmiştir.

\section{Etyoloji}

Tüm psikiyatrik bozukluklarda olduğu gibi internet bağımlıığının da etyolojisi multifaktöriyeldir. Neden internet kullanan herkeste değil de bazı kullanıcılarda bağımlılık geliştiği cevap bekleyen sorulardandır. Bozukluğu anlamada çeşitli etyolojik modeller öne sürülmektedir.

Operan koşullanma prensibine dayanan "öğrenme teorisi" bağımlı kullanıcıda coşku ve öfori gibi hislerin ortaya çıkmasına neden olan inter- netin pozitif pekiştirici etkilerini vurgulamaktadır (38). Internet ve ilişkili teknolojilerin deneyimlenmesinde kilit olay, kişinin olaydan edindiği olumlu deneyimdir. Başka bir deyişle internetin yeni bir özelliği denendiğinde ortaya çıkan sonuç olumlu ise, aynı aktiviteyi sürdürme konusunda pekiştirme oluşturur. Kişi ilk deneyimindekine benzer bir doyumu alabilmek için aktiviteyi daha sık yapmaya koşullanır. Bu edimsel koşullanma, kişi benzer fizyolojik yanıt elde etmek için yeni teknolojiler buluncaya kadar sürer. Koşullanmanın normal sürecinde bağlantılı uyaranlara yönelik bir koşullanma da gerçekleşebilir. Edimsel koşullanma ilkelerine göre, temel koşullu uyaranla ilişkili herhangi bir uyaran ikincil pekiştirme sonucu aynı tepkilere yol açabilir. Örneğin, internete bağlanan bilgisayarın sesi, klavyede yazarken oluşan dokunma duyusu, odanın kokusu gibi uyaranlar koşullanmış yanıtlar aracılığıyla aynı doyumu sağlayabilir. İkincil pekiştireçler, problemli kullanıma ait belirtilerin ortaya çıkmasını pekiştiren durumsal harekete geçiricilerin gelişmesinde ve sürdürülmesinde yardımcı etkenlerdir.

Patolojik internet kullanımını açıklamada "bilişsel-davranışçı yaklaşım", bireyin uyumsuz davranışının nedeninin, bireyin düşüncelerinden 


\begin{tabular}{|c|c|c|c|c|c|}
\hline Yazarlar & Yer & Örneklem (Sayı) & Ölçüm kriteri & Sıklık (\%) & Cinsiyet baskınlığı \\
\hline Greenfield (16) & $A B D$ & $\begin{array}{c}\text { 8-85 yaş arası bireyler } \\
\text { (17251) }\end{array}$ & Çevrimiçi anket & 5.7 & $E=K$ \\
\hline $\begin{array}{l}\text { Morahan Martin } \\
\text { Schumacher (17) }\end{array}$ & $A B D$ & Lisans öğrencileri (277) & Anket soruları & 8.1 & $E>K$ \\
\hline Chou ve Hsiao (18) & Tayvan & $\begin{array}{l}\text { Üniversite öğrencileri } \\
\text { (910) }\end{array}$ & Anket soruları & 5.9 & $E>K$ \\
\hline Whang ve ark. (19) & Kore & Katilımcılar (13588) & Young IBT & 3.5 & $E=K$ \\
\hline Kaltiala-Heino (20) & Finlandiya & Gençler (7229) & $\begin{array}{l}\text { Patolojik kumar } \\
\text { ölçeği }\end{array}$ & $\begin{array}{l}1.7(\mathrm{E}) \\
1.4(\mathrm{~K})\end{array}$ & $E>K$ \\
\hline Yoo ve ark. (21) & Kore & Kimya öğrencileri (535) & Young IBT & 0.9 & $E>K$ \\
\hline Leung (22) & Çin & $\begin{array}{c}16-24 \text { yaş arası bireyler } \\
(699)\end{array}$ & Young IBTT & 38 & $K>E$ \\
\hline Johansson ve Gotestam (23) & Norveç & $\begin{array}{c}12-18 \text { yaş arası gençler } \\
(3237)\end{array}$ & Young IBT & 2 & $E>K$ \\
\hline Niemz ve ark. (24) & İngiltere & Öğrenci (371) & Anket soruları & 18 & $E>K$ \\
\hline Kim ve ark. (25) & Kore & Öğrenci (1573) & Young IBT & 1.6 & $K>E$ \\
\hline Aboujaoude ve ark. (26) & $A B D$ & Yetişkin (2513) & Anket soruları & $0.3-0.7$ & Tanımlı değil \\
\hline Pallanti ve ark. (27) & İtalya & Öğrenci (275) & Young IBT & 5.4 & $E=K$ \\
\hline Jang ve ark. (28) & Kore & Öğrenci (912) & Young IBT & 4.3 & $E>K$ \\
\hline Ghassemzadeh ve ark.(29) & İran & $\begin{array}{l}\text { İnternet kullanan } \\
\text { bireyler (977) }\end{array}$ & Young IBT & 3.8 & Tanımlı değil \\
\hline Bakken ve ark. (30) & Norveç & Yetişkin (3399) & Young IBT & 1 & $E>K$ \\
\hline Wang ve ark. (31) & Çin & Öğrenci(14296) & Young IBT & 12.2 & $E=K$ \\
\hline Lin ve ark. (32) & Tayvan & Öğrenci (3616) & Chen IBT & 15,3 & $E>K$ \\
\hline Christakis ve ark. (33) & $A B D$ & Öğrenci (307) & Young IBT & 4 & Tanımlı değil \\
\hline Canan ve ark. (34) & Türkiye & Lise Öğrencileri (300) & Nichols IBBT & 11.6 & $E>K$ \\
\hline Kei Mak ve ark. (35) & $\begin{array}{l}\text { Hong } \\
\text { Kong }\end{array}$ & Öğrenci (860) & Chen IBT & 18 & $E>K$ \\
\hline Adiele ve ark. (36) & Nijerya & $\begin{array}{l}\text { Üniversite Öğrencileri } \\
\qquad(1022)\end{array}$ & Young İBT & 3.3 & $E>K$ \\
\hline Kuss ve ark. (37) & Hollanda & Öğrenci (3105) & Kompülsif İBT & 3.7 & Tanımlı değil \\
\hline
\end{tabular}

IBT: İnternet Bağımlılığı Testi

kaynaklandığını vurgulamaktadır. Hayatta başarısız olunan alanları gidermeye yönelik olarak geliştirilen bir davranış örüntüsü olabileceği ileri sürülmüştür (11). Davis'in ortaya attığı bu bilişsel-davranışçı modele göre, problemli internet kullanımında, uyumsuz düşünceler, davranıştan önce gelir ve esastır. Bu depresyonun bilişsel teorik açıklamasına benzer (11). İnternet gibi stres verici yeni bir ortamla karşılaşılması ve karşılaşı- lan ortamda pekiştiricilerin olması yeni bilişsel yapılanmayı oluşturmaktadır. Bireydeki düşük benlik değeri ve kendine negatif bir bakış açısından bakma, internet ile daha farklı bir gelişim sürecine girmektedir. Bu negatif bakış açısının ve düşük benlik değerinin internet ortamında chat (sohbet) odalarında fantezi rol oynama, yüzleşmeden arkadaşlık yapma ve diğer bağımlılık nesnelerine ulaşma ile telâfi edilmesi kişide 
yeni bilişsel şemaların oluşmasında önemli rol oynamaktadır. Bu arada birey gerçek hayatta yüzleşmesi gereken problemlerden de uzak kalabilmektedir. Yeni bilişsel yapılanma sürecinde en sık karşılaşılan bilişsel varsayımlar 'Ben sadece internette iyiyim', 'internette olmadığım zaman değersizim, ama internette önemli bir bireyim', 'internette olmadığımda başarısızım' şeklindeki düşünceleri yanı sıra dış dünya ile ilgili olarak da 'Saygı duyulduğum tek yer internet', 'internette olmadığım zaman kimse beni sevmiyor', 'internet benim tek arkadaşım', 'Insanlar bana internet ortamı dışında kötü davranıyor' şeklindedir. $\mathrm{Bu}$ yeni bilişsel yapılanma patolojik internet kullanımı ile sonuçlanmaktadır.

Caplan "yetersiz sosyal beceriler" diye adlandırdığı bir teori geliştirmiştir (39). Buna göre yalnız ve depresyonu olan bireyler sosyal yeterlilikleri ile ilgili negatif düşüncelere sahiptir. Düşük kendilik değerine sahip olan insanlar yüz yüze iletişim kurma yerine internet üzerinden sosyal ilişkiler kurmayı tercih ederler. Bilgisayar aracılı iletişim yüz yüze iletişime göre insanlara daha çok esneklik sağlar ve böylelikle olumsuz veya zararlı olarak görülen bilgiler rahatlıkla saklanabilir. Bu bağlamda Morahan-Martin ve Schumacher interneti "sosyal iletişimin Prozac'ı" olarak adlandırmışlardır (17).

Douglas ve arkadaşları, 1996 ve 2006 yılları arasında yayınlanmış makaleleri metaanaliz yoluyla gözden geçirmiş ve "kavramsal internet bağımlılığı modeli” önermişlerdir (40). Bu modele göre internet aşırı kullanımı, ağırlıklı olarak içsel gereksinmeler ve bireyin motivasyonu (kimliğin saklanabilmesi, sıkıntı azaltma ve rahatlatı$\mathrm{Cl}$ etkisi, sosyal gereksinmeleri karşılayabilmesi gibi itici etkenler) tarafından belirlenir. Bununla birlikte kişisel yatkınlık (öğrenci yurtları gibi internet kullanımına olanak sağlayan çevrelerde bulunma, uzun yıllar süren internet kullanımı, diğerleri tarafından yanlış anlaşıldığını hissetme, yalnızlık hissetme gibi öncüller ve aşırı internet kullanımının bir problem olduğunu reddetmeye ek olarak sosyal yaşamın ve/veya özgüvenin çok az ya da hiç olmaması gibi internet bağımlılığı profilleri) da önemlidir. Model, ortamın algılanan çekici özelliklerinin (internet üzerinden kumar, oyun, sohbet gibi bağımlılık yapıcı uygu- lamalara erişilmesi, internete ve internet üzerinden bilgiye kolay ulaşılabilirlik, sosyal etkileşimi ve fikir alışverişini kolaylaştırma, internetin diğer medya araçları arasında daha kolay haberleşmeyi sağlaması gibi çekici etkenler), itici etkenler ve internet aşırı kullanımının olumsuz etkilerinin ciddiyeti arasındaki ilişkiyi hafiflettiğini belirtir. Internet bağımlılığının olumsuz etkileri, akademik, sosyal, ekonomik, mesleki ve uyku saatleri değişiklikleri gibi fiziksel etkiler dışında ayrıca çeşitli normalden sapmış davranışları (online porno, online borsa, normal ilişki yerine sanal seks, ağır çekingenliği olanlar için sosyal faaliyetler) içerebilir. İnternet bağımlılığı probleminin kişi tarafından farkına varılması, bağımlılığı engellemek için kontrol stratejilerinin kullanılmasını kolaylaştırabilir. Bazı kişilerin diğerlerine göre normalden sapmış davranışları benimsemesi daha olasıdır; bu nedenle öncüller ve normalden sapmış davranışlar arasında doğrudan bir bağlantı önerilmiştir.

Ödül eksikliği hipotezine göre ise doğal ödüller (su, yiyecek, cinsellik) ile yeterince doyum sağlamayan bireyler ödül yolağını uyaran maddelere ve davranışlara yönelirler. Dopamin reseptör yetersizliğinden dolayı dürtüsel ve kompülsif davranışlar, alkol ve madde bağımlılığı, patolojik kumar ve bağımlılık davranışları için belirgin yatkınlık meydana gelir. Ödüllendirme ve ödül arama davranışlarına artmış hassasiyet oluşur. İnternet kullanımı alkol ve diğer maddelerin yaptığı stimülasyonu taklit ederek kısa bir gecikmeyle hızlı bir ödül olmakta, daha fazla ödül arayışı ve davranışsal motivasyon sağlamaktadır. Burada impulsivite bir risk faktörü olarak görülmektedir (41).

Internet bağımlılarıyla normal kontrol grubunun karşılaştırıldığı bir çalışmada para kazanma ve kaybetmenin olduğu bir tahmin yürütme oyunu sırasında ödül-ceza işlevleri araştırılmış ve internet bağımlılarının para kazanma sırasında orbitofrontal kortekslerinde artmış aktivasyon gözlenirken, kaybetme sırasında azalmış ön singulat aktivasyonu tespit edilmiştir. Sonuçlar internet bağımlılarında normal kontrollere oranla artmış ödül ve azalmış ceza duyarlıığını ortaya koymuştur (42).

Internet bağımlısı üniversite öğrencileriyle 
aynı sayıda kontrolün karşılaştırıldığı bir çalışmada Stroop testinde bağımlı grubun reaksiyon zamanının daha uzun olduğu ve daha fazla cevap hataları yaptığı gözlenmiştir. Çalışmada internet bağımlılarının yürütücü işlevlerini kontrol etme yeteneklerinin bozulmuş olduğu vurgulanmıştır (43). Internet oyunu ile ilişkili işaretlerin kullanıldığı bir testte yanıt inhibisyonunda ve bilişsel esneklikteki azalmaların oyun bağımlılığın devamını sağladığı başka bir çalışmada gösterilmiştir (44).

Internet bağımlılığın genetik boyutu ile ilgili az sayıda çalışma yapılmıştır. Depresyon hastalarında görülen serotonin taşıyıcı gen ekspresyonunun interneti aşırı kullanan kişilerde bakıldığ Kore kökenli bir çalışmada, interneti fazla kullananlarda serotonin taşıyıcı genin homozigot kısa allelik varyantının (SS-5HTTLPR) kontrol grubuna göre daha sık olduğu gözlenmiştir. Çalışma sonucunda aşırı internet kullanan kişilerin depresyon hastalarına benzer genetik ve kişilik özellikleri olabileceği vurgulanmıştır (45). Montag ve arkadaşlarının (2012) yaptıkları bir gen polimorfizmi çalışmasında asetilkolinin nikotinik reseptör alfa 4 subunitini (CHRNA4) kodlayan geninin T varyantını (CC genotip) internet bağımlısı olanlarda olmayanlara göre daha sık tespit etmişlerdir (46). Yine yapılan ikiz çalışmaları ise internet bağımlılığının genetik geçişinin paylaşılmamış çevresel faktörler dışlandığında \%48-66 civarında olduğunu göstermiştir $(47,48)$.

Internet bağımlılığında nörogörüntüleme ile ilgili veriler giderek artmaktadır. Yapılan bir çaIışmada online oyun bağımlısı bireylere oyun resimleri ve eşleştirilmiş görüntüler gösterilerek o sırada fonksiyonel manyetik rezonans görüntüleme (fMRI) çekilmiştir. Kontrol grubuna göre sağ orbitofrontal korteks, sağ nukleus accumbens, bilateral ön singulat ve medial frontal korteks, sağ dorsolateral prefrontal korteks ve sağ kaudat nukleusta aktivasyon gözlenmiştir (49). Benzer bölgelerde görülen aktivasyon başka çaIışmalarla da desteklenmiştir (50-52). Bu alanlar ödül yolağındaki bölgelerdir ve sonuçlar online oyun bağımlıı̆ı̆ındaki aşırı oyun isteği ile madde bağımlılığındaki maddeye olan aşermenin aynı nörobiyolojik mekanizmaları paylaşabileceğini göstermektedir. İnternet bağımlısı ergenlerin katıldığı başka bir nörogörüntüleme çalışmasında uzun dönem internet bağımlılığının beyinde yapısal değişikliklere neden olduğu gösterilmiştir (53). Yine Kim ve arkadaşlarının (2011) yaptığı bir çalışmada ise araştırıcılar pozitron emisyon tomografisi (PET) ile internet bağımlılığı olan ve olmayan erişkin erkeklerde dopamin D2 reseptör bağlanma seviyelerine bakmış, internet bağımlılığı olan bireylerin her iki taraf dorsal kaudat nukleus ve sağ putamen bölgelerini içeren striatumda dopamin D2 reseptör seviyelerinde azalma olduğu saptanmıştır (54). Başka bir tek foton emisyonlu bilgisayarlı tomografi (SPECT) çalışmasında ise benzer şekilde internet bağımIısı olan bireylerin beyinde striatum bölgesinde azalmış dopamin taşıyıcı seviyeleri gösterilmiştir (55). Bu sonuçlar da bağımlılık etiyolojisinde yer alan ödül eksikliği hipotezini doğrular niteliktedir.

\section{Komorbidite}

Internet bağımlılığı ile ilgili şimdiye kadar yapılan araştırmalar internet bağımlılarında sıklıkla psikiyatrik bozuklukların bulunduğunu ortaya koymaktadır (56). Hatta problemli internet kullanımı olan bireylerde diğer psikiyatrik hastalıkların varlığının istisnadan ziyade bir kural olduğu belirtilmektedir.

Black ve arkadaşları (1999) yetişkinlerle yaptıkları bir çalışmada internet bağımlılarının \%50'sinde başka bir psikiyatrik bozukluk bulunduğunu ortaya koymuştur (57). Shapira ve arkadaşlarının (2000) yaptığı bir çalışmada araştırıcılar problemli internet kullanımı olan bireylerin \% 70 'inde duygudurum bozuklukları (depresyon \% 10, bipolar \%60), \% 60'ınde anksiyete bozukluğu (en sık sosyal anksiyete bozukluğu \% 40), \% 10'unda madde kötüye kullanımı/bağımlılığı (yaşam boyu \% 55) tespit etmişlerdir (58). Bernardi ve arkadaşlarının (2009) yetişkin internet bağımIılarıyla yaptığı başka bir çalışmada ise dikkat eksikliği ve hiperaktivite bozukluğu (DEHB) (\%14), hipomani (\%7), yaygın anksiyete bozukluğu (\%15), sosyal anksiyete bozukluğu (\%15), distimi (\%7), obsesif kompülsif kişilik bozukluğu (\%7), borderline kişilik bozukluğu (\%14) ve çekingen tip kişilik bozukluğu (\%7) komorbid psikiyatrik 
tanılar olarak gözlenmiş ve aynı çalışmada dissosiyatif deneyimler ölçeğinde görülen yüksek skorların internet bağımlılığının şiddeti ile ilişkili olduğu vurgulanmıştır (59).

Yapılan bazı çalışmalarda aşırı internet kullanımının depresyon, ölüm-intihar düşünceleri, düşük benlik saygısı, yalnızlık ve sosyal izolasyon ile ilişkili olduğu bulunmuş ve yine depresyon ölçeği skorlarının internet bağımlılarında daha yüksek olduğu tespit edilmiştir $(60,61)$.

De Berardis ve arkadaşlarının (2009) İtalyan ergenlerde yaptığı bir çalışmada ise aleksitimi, dissosiyatif deneyimler, düşük benlik saygısı ve dürtü kontrol güçlükleri gibi faktörlerin internet bağımlılığı için risk faktörleri olabileceği vurgulanmıştır (62). Tsitsika ve arkadaşlarının (2011) yaptıkları vaka kontrollü bir çalışmada internet bağımlısı 83 ergen ile yaş ve cinsiyet eşleştirilmiş bağımlı olmayan 43 ergeni karşılaştırmışlardır. Bağımlı grupta 3.8 kat daha fazla komorbid psikiyatrik durumlar saptanmış olup; internet bağımlıığının bozulmuş aile fonksiyonları, düşük akademik performans, yüksek riskli aktivitelere bulaşma ve artmış depresyon ile ilişkili olduğu belirlenmiştir (63).

Güney Koreli 535 ilköğretim öğrencisiyle yapılan bir çalışmada Yoo ve arkadaşları (2004) problemli internet kullandıkları belirlenen 80 öğrencinin \% 30'unda aynı zamanda DEHB semptomları olduğunu saptamışlardır (64). Ko ve arkadaşlarının (2008) 216 Tayvanlı üniversite öğrencisiyle yaptıkları başka bir çalışmada ise problemli internet kullanımı olanlarda DEHB oranı \% 32 iken olmayanlarda oran \% 8 olarak bulunmuştur (65). Yine Tao ve arkadaşları (2009) 12-25 yaş arası internet bağımlısı lise ve üniversite öğrencileriyle ile yaptıkları bir çalışmada öğrencilere yeme tutum testi ile yeme bozuklukları envanteri uygulamışlar ve bağımlı grupta yeme bozuklukları skorlarının belirgin derecede daha yüksek olduğunu bulmuşlardır (66).

Ülkemizde ise Tahiroğlu ve arkadaşları (2010) yaptıkları bir çalışmada psikiyatrik bozukluğu olan ve olmayan ergenlerde internet kullanım özellikleri ve problemli internet kullanımını araştırmışlardır. Psikiyatrik bozukluğu olan (en sık DEHB sonra kaygı, duygudurum ve diğer bozukluklar) ergenlerin \% 23,3'ü haftada 8 saatten daha fazla internet kullandığını bildirirken, toplum örnekleminde bu oran \% 10,6 bulunmuştur. Çalışma sonucunda ergenlerde psikopatoloji ile problemli internet kullanımı ilişkisi ortaya konmuş ve bu ilişkinin DEHB grubunda daha belirgin olduğu vurgulanmıştır (67). Yine Bozkurt ve arkadaşlarının (2013) internet bağımlılığı olan ergenlerde yapılandırılmış görüşme tekniği kullanarak yaptıkları çalışmada ise sırasıyla DEHB, sosyal fobi ve majör depresyon en fazla psikiyatrik eş tanılar olarak tespit edilmiştir (68).

Yapılan çalışmalar göz önünde bulundurulduğunda ruhsal bozukluğa sahip olmanın internet bağımlılığına yatkınlık mı oluşturduğu yoksa internet bağımlılığının ruhsal hastalıkların ortaya çıkmasını kolaylaştıran bir durum mu olduğu henüz tam aydınlanmamıştır. Pek çok yazar, olguya göre her ikisinin de doğru olabileceği ve bu iki durumun birbirinin tetikleyicisi olarak göründügü fikrine sahiptir $(65,69)$.

\section{Klinik ve Tedavi Yaklaşımları}

Tipik bir internet bağımlısı haftada $40-80$ saat arasında bilgisayar başında kalmakta ve tek seferde hiç aralıksız 20 saate kadar bilgisayar başından kalkmayabilmektedir. Uyku döngüsü bozulan hasta uyarıcı madde kullanmaya aşırı kahve ve kolalı içecekler tüketmeye başlayabilir, fiziki aktivitenin giderek azalmasına bağlı obezite, karpal tünel sendromu, sırt ağrısı ve postür bozuklukları gelişebilir (8).

Problemli internet kullanımı için yukarıda da ifade edilen görünüm özellikleri birbirlerine benzemektedir. Öncelikle internetle ilgili bilişsel durum dikkati çekmektedir. İnternet hakkında takıntılı düşünceler, azalmış dürtü kontrolü, internet kullanımını azaltamama ya da kesememe, internet dışındayken sürekli interneti düşünme, bir dahaki internete bağlanma anını sabırsızlıkla bekleme, internetin tek arkadaşı olduğunu düşünme gibi belirtiler göze çarpmaktadır. İnternet kullanımı sorunlu hale gelmiş kişide görülebilecek diğer özellikler ise; internete çok para harcama, yaşamındaki diğer bazı etkinliklere daha az zaman ayırma, kendini sosyal çevresinden izole etme, internette kalış süresi konusunda ailesine ve arkadaşlarına yalan söyleme, uyku düzenin- 
de değişiklik/ uykusuzluk, akademik / iş ya da kişilerarası ilişkilerde sorunlar, sosyal çevrenin, ailenin, işin ya da kişisel sorumlulukların ihmal edilmesi, internetten uzak kalmaya çalışıldığında huzursuzluk hissetme, planladığından daha uzun süre internette kalma, fiziksel etkinliklerde genel bir azalma ve buna bağlı kilo alma, kafein alımını arttırma, bağışıklık sisteminin zayıflamasına bağlı bazı fiziksel hastalıklara yatkınlık, uzun süre hareketsiz kalmaya bağı boyun ve sırt ağrılarıdır. Problemli internet kullanımının göstergesi sayılan bu belirtilerin bir kısmı aslında sadece internet kullanımı değil, bilgisayar kullanımına bağlı ortaya çıkan belirtilerdir. Bir önemli nokta da problemli internet kullanımının belli yaş grupları ve cinsiyetler arasındaki farklı görünümlerinin olmasıdır.

İnternet bağımlılığının tedavisi ile ilgili kanıta dayalı tedavi stratejileri olmasa da hem farmakoterapi hem de psikoterapi yöntemleri önerilmektedir (Tablo 5).

\begin{tabular}{|l|l|}
\hline \multicolumn{2}{|l|}{ Tablo 5: İnternet Bağımlılı̆ı Tedavi Yöntemleri. } \\
\hline 1. Farmakoterapi & 2. Psikoterapi \\
\hline • Antidepresanlar (AD) & • Bilişsel davranışçı terapi \\
(SSRI, venlafaksin, bupropion) & • Aile terapisi \\
• Duygudurum düzenleyicileri & • Destek grupları \\
(DDD) & • Rehabilitasyon merkezleri \\
(lityum, gabapentin, valproat) & \\
• Kombine AD ve DDD & \\
- Anksiyolitikler & \\
- Naltrekson & \\
\hline
\end{tabular}

SSRI: Seçici Serotonin Geri Alım İnhibitörleri

Internet bağımlılığında tedavi hedefi öncelikle eğer saptanabilmişse altta yatan psikiyatrik bozukluğun tedavi edilmesidir. Yapılan çalışmalar sonucu kişilerin internet ile ilişkili semptomlarının kompülsif - egodistonik olmaktan ziyade daha çok impulsif - egosintonik olduğu vurgulanmaktadır. Bu yüzden internet bağımlılığı dürtü kontrol bozuklukları tanımına daha çok uymaktadır. Eğer patolojik internet kullanımı bir diğer psikiyatrik bozukluğun belirtisi değilse dürtü kontrol bozukluğuna daha yakın olması nedeniyle farmakoterapi SSRI ve duygudurum düzenleyiciler ile başlar. Bugüne dek bu grup ilaçlarla çift kör plasebo kontrollü bir çalışma yapılmamıştır.
Essitalopram ile yapılan bir çalışmada (19 olgu, 20mg/gün) 10 haftalık sürede internet kullanım süresinde büyük oranda düşüşler görülmüş, 10 haftadan sonra olguların bir kısmı essitalopram ile devam ederken bir kısmına plasebo verilmiştir. 9 haftalık izlem sürecinde plasebo alan grup ile essitalopram alan grup arasında ilk 10 haftadaki kazanımlar açısından bir fark bulunmamıştır (70).

Citalopram ve Ketiapin kullanımı ile bir olgu sunumunda internet kullanımında azalma saptanırken 4 aylık izlem boyunca relaps görülmemiş$\operatorname{tir}(71)$.

Farmakoterapötik anlamda oldukça yenilikçi olan bir başka yaklaşım ise eşlik eden psikiyatrik bozukluklarının tedavisinin yanı sıra bağımIılığın kendisini tedavi etmeye yönelik olarak özellikle sanal seks bağımlılarında naltrekson kullanılmasıdır. Naltrekson kullanımıyla ilgili olarak yayınlanan bir çalışmada Bostwick ve Bucci (2008), kompülsif ve öforik bir şekilde internet pornografisine bağımlı olan bir kişide naltrekson tedavisiyle ciddi bir düzelme görüldüğünü belirtmişlerdir (72). Bilindiği gibi, naltrekson aslında alkol-madde bağımlılığı tedavisinde kullanılan bir opiyat antagonisti olup, opiyatların dopamin salınımını arttırıcı etkilerini önler. Ödül merkezinin ve dopaminin işlev bozukluğunun bağımlılıktaki rolü nedeniyle, naltreksonun ödül merkezi üzerinde gösterdiği bu etkinin önemli bir tedavi aracı olabileceği düşünülebilir.

Sigara bağımlılığı tedavisinde kullanılan ve aynı zamanda bir antidepresan olan bupropion ile yapılan bir çalışmada Starcraft oyunu bağımlısı 11 kişi (oyun; >30 saat/hafta) ve 8 sağlıklı kontrol (oyun; <3 gün/hafta, <1saat/gün) çalışmaya alınmış, başlangıç ve 6 haftalık bupropion tedavisi sonucu Starcraft görüntüleriyle beyinde oluşan aktivasyon cevabı fMRI ile karşılaştırılmıştır. 6 haftalık bupropion tedavisiyle bağımlı grupta dorsolateral prefrontal kortekste oyun görüntüleri ile tetiklenen artmış beyin aktivasyonunda azalma, oyun isteğinde ve total oyun oynama süresinde düşüş gözlenmiştir (73). Yine online oyun bağımlısı ve beraberinde depresyonu da olan 50 kişiye rastgele bupropion ve plasebo ve- 
rilerek yapılan bir çalışmada 12 haftalık tedavi sonunda bupropion alan grupta Young internet bağımlılığı skorlarının plasebo alan gruba göre daha fazla azaldığı tespit edilmiştir. Yine aynı çaIışmada bupropionun hem depresif semptomları iyileştirmede hem de aşırı oyun oynamanın şiddetini azaltmada etkili olduğu gösterilmiştir (74).

Aşırı online oyun oynayan ve DEHB olan 62 çocukla (ortalama yaş 9) yapılan bir çalışmada 8 haftalık metilfenidat (uzun salınımlı) tedavisinden sonra hem DEHB hem de internet bağımlılığı skorlarında düşüş gözlenmiştir. Bu çalışma ile DEHB'li olan çocuklarda internet oyunu oynamanın bir nevi kendi kendini tedavi etme biçimi olduğu ve bu çocuklarda metilfenidat tedavisinin internet bağımlılığı tedavisinde önemli etkisi olduğu belirtilmiştir (75).

Internet bağımlılığının tedavisinde bir diğer seçenek; farmakoterapiye ek olarak ya da farmakoterapiden bağımsız olarak bilişsel-davranışçı yöntemlerin kullanılmasıdır. Araştırıcılar, internet bağımlılığında tıpkı depresyonda olduğu gibi bazı olumsuz bilişlerin rol oynadığını ve internet bağımlılığının hayatta başarısız olunan alanları telafi etmeye yönelik bir davranış örüntüsü olarak ortaya çıktığını öne sürmüşler ve bu bağlamda internetin aşırı kullanımının ödüllendirici bir davranış olarak görülebileceğini ve öğrenme mekanizmaları aracılığıyla bazı olumsuz duygularla (korku, huzursuzluk, hayal kırıklığı) mücadele etmeye yarayan yetersiz bir strateji olarak kullanılabileceğini belirtmişlerdir. İnternet bağımlıı̆̆ının tüm bu bilişsel özellikleri dikkate alındığında bilişsel-davranışçı tekniklerin bu bozukluğun tedavisinde önemli yeri olacağı açıktır. Bu noktadan hareketle Davis, bu hastalarda kullanılabilecek bir bilişsel-davranışçı tedavi protokolü önermiştir (11) (Tablo 6).

Young ise, internet bağımlılığının bilişsel-davranışçı tedavisinde internete girmeyi yasaklamanın pek uygun bir çözüm yolu olmadığını çünkü internet kullanımının banka işlemleri yapmak gibi işlemler için bir ihtiyaç olduğunu belirtmiş ve tedavi hedefinin, interneti tamamen yasaklamak yerine internet kullanımının kontrol altına alınması olması gerektiği ifade etmiştir (76).
Tablo 6: Davis'in Önerdiği Bilişsel-Davranışçı Tedavide Atılması Gereken Adımlar

1. Kişinin internetten uzak kalıp kalamadığının tespiti

2. Bilgisayarın yerinin değiştirilmesi ve diğer insanların bulunduğu yere nakli

3. Diğer insanlar ile beraber internete bağlanması

4. Internete bağlanma zamanını değiştirmesi

5. Internet defteri oluşturması

6. Persona kullanımına son vermesi

7. Arkadaşlarından ve yakınlarından internet ile ilgili problemleri olduğunu saklamaması

8. Spor aktivitelerine katıması

9. Internet tatillerinin verilmesi

10. Otomatik düşüncelerin ele alınması

11. Gevşeme egzersizleri

12. İnternete bağlanma sırasında hissedilenlerin not edilmesi

13. Yeni sosyal becerilerin kazandırılması

Şimdiye kadar internet bağımlılığının tedavisi için yukarıda önerilmiş olan yöntemlerin etkinliğini araştıran pek fazla çalışma bulunmamakla beraber Young, kurmuş olduğu internet bağımlılığı tedavi merkezine başvuran 114 kişiyle yaptığı bir çalışmada, bilişsel-davranışçı tedavinin etkinliğini motivasyon, zamanı kullanma becerisi, sosyal etkinliklerde düzelme, cinsel işlevlerde düzelme, sanal olmayan etkinliklere katılma ve sorun oluşturan internet işlevlerinden uzak durabilme bağlamında bir anket çalışması ile değerlendirmiş ve 6 ay boyunca 3, 8 ve 12. haftalarda bu anketi tekrarlamıştır. Sonuç olarak, danışanların çoğunun 8 haftalık seanslar sonrasında başvuru anındaki belirtileriyle baş etmeye başladıklarını ve 6 aylık izlemde bu iyilik hallerini koruduklarını belirtmiştir (76).

\section{SONUÇ}

Internet kullanımının hayatın vazgeçilmez bir gereci haline geldiği bu teknoloji çağında internetin patolojik kullanımı yeni bir bağımlılık türü olarak nitelenebilecek internet bağımlılığına yol açmaya başlamıştır. Uzun süre kontrolsüz bilgisayar ve internet kullanımı bireylerin fiziksel, psikolojik, sosyal, bilişsel sağlığını ve yaşamını olumsuz yönde etkilemektedir. Ülkemizde internet bağımlılığı problemi daha ziyade bu teknolojiye daha hakim olan gençlerde ve çocuklarda daha fazla görülmektedir ve artık aileler çocuklarının 
internet kullanımının yol açtığı sorunlar nedeniyle bu bozukluğun tedavisini yapabilecek merkezlerin arayışına girmeye başlamıştır. Ülkemiz için henüz yeni olan bu sorunu uzun bir süredir yaşamakta olan uzak doğu ülkelerinde ve ABD'de artık bu bozuklukla ilgili tedavi merkezleri oluşturulmuş ve hızla bu konuda deneyimli klinisyenlerin yetiştirilmesine başlanmıştır. Gelecekte, ülkemiz için de bu tip tedavi merkezlerinin kurulmasına ihtiyaç duyulabileceği yüksek ihtimal dâhilindedir. Bu nedenle başta çocuk ve ergen ruh sağlığı hekimleri olmak üzere tüm klinisyenlerin bu bozukluk konusunda yeterli bilgiye sahip olmaları, bu bozukluğu tanımaları ve uygun tedavi yaklaşımları sergilemeleri büyük önem arz etmektedir.

\section{KAYNAKLAR}

1. Young KS. Internet addiction. Am Behav Sci 2004; 48: 402-441.

2. Griffiths MD. Internet addiction: An issue for psychopathology? Clinical Psychology Forum 1996; 97: 32 36.

3. Beard KW. Internet addiction: a review of current assessment techniques and potential assessment questions. Cyberpsychol Behav 2005; 8: 7-14.

4. Koyama A, Miyake Y, Kawakami N, Tsuchiya M, Tachimori $\mathrm{H}$, Takeshima T. Lifetime prevalence, psychiatric comorbidity and demographic correlates of "hikikomori" in a community population in Japan. Psychiatry research 2010; 176: 69-74.

5. Davis, RA. What is internet addiction? Available at: www.victoriapoint.com/internetaddiction/articles, 2002.

6. Shaw M, Black DW. Internet addiction: definition, assessment, epidemiology and clinical management. CNS Drugs 2008; 22: 353-365.

7. Goldberg I. Internet Addiction Disorder. www.cog. brown.edu/brochure/people/duchonf/humor/internetaddiction.html, 1999.

8. Young KS. Internet addiction: The emergence of a new clinical disorder. Cyberpsychol Behav 1996; 3: 237 244.

9. Griffiths M. Internet addiction. The Psychologist 1999; 12: $246-251$

10. Beard KW, Wolf EM. Modification in the proposed diagnostic criteria for Internet addiction. Cyberpsychol Behav 2001; 4: 377-383.

11. Davis RA. A cognitive-behavioral model of pathological Internet use (PIU). Computers in Human Behavior 2001; 17:187-195

12. Shapira NA, Lessig MC, Goldsmith TD ve ark. Problematic internet use: proposed classification and diagnostic criteria. Depress Anxiety 2003; 17: 207-216.

13. Ko CHH, Yen JYY, Chen CCC, Chen SHH, Yen CFF. Proposed Diagnostic criteria of Internet addiction for adolescents. The Journal of nervous and mental disease. 2005; 193: 728-733.
14. Douglas A, Mills J, Niang M, Stepchenkova S, Byun S, Ruffini C. Internet addiction: Meta-synthesis of qualitative research for the decade 1996-2006. Computers in Human Behavior 2008; 24: 3027-3044.

15. Tao R, Huang $X$, Wang J, Zhang H, Zhang $\mathrm{Y}$, Li M. Proposed Diagnostic criteria for Internet addiction. Addiction 2010; 105: 556-564.

16. Greenfield DN. Psychological characteristics of compulsive Internet use: a preliminary analysis. Cyberpsychol Behav 1999; 2: 403-412.

17. Morahan-Martin J, Schumacher P. Incidence and correlates of pathological Internet use among college students. Comput Human Behav 2000; 16: 13-29.

18. Chou C, Hsiao MC. Internet addiction, usage, gratification, and pleasure experience: the Taiwan college students' case. Comput Educ 2000; 35: 65-80.

19. Whang LS, Lee $S$, Chang G. Internet over-users' psychological profiles: a behavior sampling analysis on Internet addiction. Cyberpsychol Behav 2003; 6: 143150.

20. Kaltiala-Heino R, Lintonen T, Rimpela A. Internet addiction? Potentially problematic use of the Internet in a population of 12-18 year old adolescents. Addict Res Theory 2004; 12: 89-96.

21. Yoo HJ, Cho SC, Ha J, Yune SK, Kim SJ, Hwang J. Attention deficit hyperactivity symptoms and Internet addiction. Psychiatry Clin Neurosci 2004; 58: 487-494.

22. Leung L. Net-generation attributes and seductive properties of the Internet as predictors of online activities and Internet addiction. Cyberpsychcol Behav 2004; 7: 333-48.

23. Johansson A, Gotestam K. Internet addiction: characteristics of a questionnaire and prevalence in Norwegian youth (12-18 years). Scand J Psych 2004; 45: 223-229.

24. Niemz K, Griffiths M, Banyard P. Prevalence of pathological Internet use among university students and correlations with self-esteem, the General Health Questionnaire (GHQ) and disinhibition. Cyberpsychol Behav 2005; 8: 562-570. 
25. Kim K, Ryu E, Chon MY, Yeun EJ, Choi SY, Seo JS. Internet addiction in Korean adolescents and its relationship to depression and suicidal ideation: a questionnaire survey. Int J Nurs Stud 2006; 43: 185-192.

26. Aboujaoude E, Koran LM, Gamel N, Large MD, Serpe RT. Potential markers for problematic Internet use: a telephone survey of 2,513 adults. CNS Spectr 2006; 11: 750-755.

27. Pallanti S, Bernardi S Leonardo Q. The shorter PROMIS questionnaire and the internet addiction scale in the assessment of multiple addictions in a high-school population: prevalence and related disability. CNS Spectr 2006; 11: 966-974.

28. Jang KS, Hwang SY, Choi JY. Internet addiction and psychiatric symptoms among Korean adolescents. J Sch Health 2008; 78: 165-171.

29. Ghassemzadeh L, Shahraray M, Moradi A. Prevalence of Internet addiction and comparison of Internet addicts and non-addicts in Iranian high schools. Cyberpsychol Behav 2008; 11: 731-733.

30. Bakken IJ, Wenzel HG, Götestam KG. Internet addiction among Norwegian adults: a stratified probability sample study. Scand J Psychol 2009; 50: 121-127.

31. Wang H, Zhou X, Lu C, Wu J, Deng X, Hong L. Problematic Internet Use in high school students in Guangdong Province, China. PLoS One. 2011; 6: 196-203.

32. Lin MP, Ko HC, Wu JY. Prevalence and Psychosocial Risk Factors Associated with Internet Addiction in a Nationally Representative Sample of College Students in Taiwan. Cyberpsychol Behav Soc Netw. 2011

33. Christakis DA, Moreno MM, Jelenchick L, Myaing MT, Zhou C. Problematic internet usage in US college students: a pilot study. BMC Med. 2011; 22: 69-77.

34. Canan F, Ataoglu A, Nichols LA, Yildirim T, Ozturk O. Evaluation of psychometric properties of the internet addiction scale in a sample of Turkish high school students. Cyberpsychol Behav Soc Netw. 2010; 13: 317 320.

35. Mak KK, Lai CM, Ko CH ve ark. Psychometric properties of the Revised Chen Internet Addiction Scale (CIAS-R) in Chinese adolescents. J Abnorm Child Psychol. 2014; 42: 1237-1245.

36. Adiele I, Olatokun W. Prevalence and determinants of Internet addiction among adolescents. Computers in Human Behavior 2014; 31: 100-110.

37. Kuss DJ, van Rooij AJ, Shorter GW ve ark. Internet addiction in adolescents: Prevalence and risk factors. Computers in Human Behavior 2013; 29: 1987-1996.

38. Wallace P. The Psychology of the Internet. Cambridge University Press, New York 1999.

39. Caplan SE. Preference for online social interaction: a theory of problematic internet use and psychosocial well-being. Comm Research 2003; 30: 625-48.
40. Douglas A, Mills J, Niang M, Stepchenkova S, Byun S, Ruffini C. Internet addiction: Meta-synthesis of qualitative research for the decade 1996-2006. Comput Human Behav 2008; 24: 3027-3044.

41. Blum K, Cull JG, Comings ED. Biogenetics of reward deficiency syndrome. Sci Am 1996; 84: 132-145.

42. Dong G, Huang J, Du X. Enhanced reward sensitivity and decreased loss sensitivity in Internet addicts: An fMRI study during a guessing task. J Psychiatr Res. 2011.

43. Dong G, Zhou H, Zhao X. Male Internet addicts show impaired executive control ability: evidence from a color-word Stroop task. Neurosci Lett 2011; 499: 114118.

44. Zhou,Z.,Yuan,G.,andYao,J.(2012).CognitivebiasestowardInternetgame-related picturesandexecutivedeficitsinindividualswithanInternetgameaddiction.PLoSONE

45. Lee YS, Han DH, Yang KC, Daniels MA, Na C, Kee BS. Depression like characteristics of 5HTTLPR polymorphism and temperament in excessive Internet users. J Affect Disord 2008; 109: 165-169.

46. Montag C, Kirsch P, Sauer C, Markett S, Reuter M. The role of the CHRNA4 gene in Internet addiction: a casecontrol study. J Addict Med. 2012; 6: 191-195.

47. Vink JM, van Beijsterveldt TC, Huppertz C, Bartels M, Boomsma DI. Heritability of compulsive Internet use in adolescents. Addict Biol. 2015 Jan 13.

48. Li M, Chen J, Li N, Li X. A twin study of problematic internet use: its heritability and genetic association with effortful control. Twin Res Hum Genet. 2014; 17: 279-287.

49. Ko $\mathrm{CH}$, Liu GC, Hsiao S ve ark. Brain activities associated with gaming urge of online gaming addiction. J Psychiatr Res 2009; 43: 739-747.

50. Han D, Kim Y, Lee Y. Changes in cue induced prefrontal cortex activity with video game play. Cyberpsychol Behav Soc Netw 2010; 13: 655-661.

51. Ko C, Liu GC, Yen JY ve ark. Brain correlates of craving for online gaming under cue exposure in subjects with Internet gaming addiction and in remitted subjects. Addict Biol 2013; 18: 559-569.

52. Lorenz RC, Kruger JK, Neumann B ve ark. Cue reactivity and its inhibition in pathological computer game players. 2013; 18: 134-146.

53. Yuan K, Qin W, Wang G. Microstructure abnormalities in adolescents with internet addiction disorder. PLoS One 2011; $6: 6$.

54. Kim Sang Hee, Baik Sang Hyun, Park Chang Soo. Reduced striatal dopamine D2 receptors in people with Internet addiction. NeuroReport Issue 2011; 22: 407411 
55. Hou H, Jia S, Hu S ve ark. Reduced striatal dopamine transporters in people with internet addiction disorder. J Biomed Biotechnol. 2012; 2012: 854524.

56. Ko CH, Yen JY, Yen CF, Chen CS, Chen CC. The association between Internet addiction and psychiatric disorder: a review of the literature. Eur Psychiatry 2012; 27: 1-8.

57. Black DW, Belsare G, Schlosser S. Clinical features, psychiatric comorbidity. and health-related quality of life in persons reporting compulsive computer use behavior. J Clin Psychiatry 1999; 60: 839-43.

58. Shapira N, Goldsmith T, Keck JP. Psychiatric features of individuals with problematic internet use. J Affect Disord 2000; 57: 267-72

59. Bernardi S, Pallanti S. Internet addiction: a descriptive clinical study focusing on comorbidities and dissociative symptoms. Compr Psychiatry 2009; 50: 510-516.

60. Kraut R, Patterson M, Lundmark V, Kiesler S, Mukophadhyay $\mathrm{T}$, Scherlis $\mathrm{W}$. Internet paradox: a social technology that reduces social involvement and psychological well-being? Am Psychol 1998; 53: 1017 1031.

61. Young KS, Rodgers RC. The relationship between depression and Internet addiction. Cyberpsychol Behav 1998; 1: 25-28.

62. De Berardis D, D'Albenzio A, Gambi F. Alexithymia and its relationships with dissociative experiences and Internet addiction in a nonclinical sample. Cyberpsychol Behav 2009; 12: 67-69.

63. Tsitsika A, Critselis E, Louizou A. Determinants of Internet addiction among adolescents: a case-control study. ScientificWorldJournal 2011; 11: 866-874.

64. Yoo HJ, Cho SC, Ha J ve ark. Attention deficit hyperactivity symptoms and Internet addiction. Psychiatry Clin Neurosci 2004; 58: 487-494.

65. Ko CH, Yen JY, Chen CS. Psychiatric comorbidity of Internet addiction in college students: an interview study. CNS Spectr 2008; 13: 147-153.

66. Tao ZL, Liu Y. Is there a relationship between Inter- net dependence and eating disorders? A comparison study of Internet dependents and non-Internet dependents. Eat Weight Disord 2009; 14: 77-83.

67. Tahiroglu AY, Celik GG. Psikiyatrik Bozukluğu Olan ve Olmayan Ergenlerde Problemli İnternet Kullanımı. Nöropsikiyatri Arşivi 2010; 47: 241-246.

68. Bozkurt H, Coskun M, Ayaydin H, Adak I, Zoroglu SS. Prevalence and patterns of psychiatric disorders in referred adolescents with Internet addiction. Psychiatry Clin Neurosci. 2013; 67: 352-359.

69. Shaffer HJ, Hall MN, Vander Bilt J. "Computer addiction": a critical consideration. Am J Orthopsychiatry 2000; 70: 162-168.

70. Dell' Osso B, Altamura AC, Hadley SJ, Baker BR, Hollander $\mathrm{E}$. An open label trial of escitalopram in the treatment of impulsive-compulsive Internet usage disorder. European Neuropsychopharmacology 2007; 16: 82-83.

71. Atmaca M. A case of problematic internet use successfully treated with an SSRI-antipsychotic combination. Prog Neuropsychopharmacol Biol Psychiatry 2007; 31: 961-962.

72. Bostwick JM, Bucci JA. Internet sex addiction treated with naltrexone. Mayo Clin Proc 2008; 83: 226-230.

73. Han DH, Hwang JW, Renshaw PF. Bupropion sustained release treatment decreases craving for video games and cue-induced brain activity in patients with Internet video game addiction. Exp Clin Psychopharmacol 2010; 18: 297-304.

74. Han DH, Renshaw PF. Bupropion in the treatment of problematic online game play in patients with major depressive disorder. J Psychopharmacol 2011.

75. Han D, Lee $Y, N a C$ ve ark. The effects of methylphenidate on Internet video game play in children with attention-deficit/hyperactivity disorder. Compr Psychiatry 2009; 50: 251-256.

76. Young KS. Cognitive behavior therapy with internet addicts: treatment outcomes and implications. Cyberpsychol Behav 2007; 10: 671-679. 